\title{
The Impact of Global Financial Crisis on Jordan
}

\author{
Mohammad Ahid ${ }^{1} \&$ Ayuba Augustine ${ }^{2}$ \\ ${ }^{1}$ College of Business, Universiti Utara Malaysia Sintok, Kedah, Malaysia \\ ${ }^{2}$ Department of Accounting, Kaduna State University, Kaduna State, Nigeria \\ Correspondence: Mohammad Ahid, College of Business, Universiti Utara Malaysia Sintok, 06010 Kedah, \\ Malaysia. E-mail: mohammadahed83@yahoo.com
}

Received: April 22, 2012 Accepted: May 31, 2012 Online Published: August 16, 2012

doi:10.5539/ijbm.v7n16p80 URL: http://dx.doi.org/10.5539/ijbm.v7n16p80

\begin{abstract}
The paper discusses the impact of global financial crisis on the Jordanian economy in two periods; the first period extended from the beginning of the global crisis in autumn of 2008 to December 2008, and the second period started from December 2008 till the end of 2011. The results of this paper indicate that the impact of the global crisis is being driven by the country's high dependence on foods and oil prices which led to increase the prices of oil and commodity. We also found that the banking and tourism sectors were not affected by the crisis. The evidence is presented in a series of charts which are backed up by statistical analysis.
\end{abstract}

Keywords: global financial crisis, Jordanian economy

\section{Background of Jordan's Economy}

Like some of the Arabic countries, Jordan, which is a small Arabic country located in the Middle East, is characterized by possessing a small industrial base. Strikingly, its economy is among the smallest in the region because of the scarcity of its natural resources. Furthermore, the country is known for high standards of unemployment among its educated and uneducated citizens, especially the youth. Despite these facts, there has been a steady growth in the economy.It is noted that the Jordanian economy has mainly grown increasingly over the past 20 years. Great deal of significant economic reforms have been carried out by King Abdullah II Since he has been in power in 1999, these included opening the trade regime, privatizing state-owned companies, and abolishment of most fuel subsidies. Hence, these critical reforms have been the primary motivator for foreign investment in the kingdom in the last few years. The economic growth has improved increasingly as a result of the foreign investment which naturally has led to creating more job opportunities. Undeniably, the rate of unemployment has decline considerably despite the sweeping global financial crisis which casted its light on the whole region.

It is taken-by-granted that Jordan was affected by the financial crisis; there were imbalance in the level of imports and exports, I.e. Jordan had to pay more for basic commodities and energy products including oil. Despite the challenges, the country has moved on in implementing the significant reforms therefore the economic growth increased constantly. It is understood that any country must prioritize the annual economic growth by implementing strategic economic plans that would be ready to face any sudden or undesirable economic imbalances.

Jordan's economy is mainly dependent on exports, tourism, and overseas Jordanian employees' remittances. Any imbalances in these economic resources will affect the rate of employment and unemployment in the kingdom. By nature of things, as the rate of unemployment increases more, the rate of poverty will rise in Jordan. Noticeably, now the rate of poverty in Jordan has reached $14.5 \%$ according to the official statistical estimates. However, the rate is higher based on nongovernmental institutions - estimated at 27\%, (European Economy, 2009). On the other hand, Like some underdeveloped countries, Jordan has been suffering greatly from "brain drain"; there are approximately 600,000 Jordanians working abroad, nearly $50 \%$ of them have workplaces in the Gulf region, and their remittances are up to $20 \%$ of the JordanianGDP, (European Commission, 2009).In other words, remittances are recognized as an important national income to the country. It is agreed that, among the huge number of Jordanians working overseas, there are a big number of academic, skilled and professional people. This undoubtedly, despite the advantageous benefits, negatively affects the country since Jordan needs to make up the shortage by depend on alterative foreign manpower from Egypt and Syria. Consequently, this leads 
to transfer huge amounts of foreign currency outside the country; cash outflow. The point is that the foreign laborers from the Arab neighboring countries are not as professional as the Jordanians; the vast majority of them work in the field of construction.

Considerably, the Jordanian economy is very service-oriented and heavily dependent on foreign grants which have affected the kingdom depending on the magnitude of these grants. According to Jordan's ministry of finance, the grants increased by $102 \%$ (from $\$ 484$ million to $\$ 980$ million). In the same context, the budget deficit is another huge challenge to the Jordanian government, which forces the government to continue depending on foreign grants and assistances.

It is inferred that, in the light of the recent global economic crisis, Jordan has faced several challenges due to the impact of global downturn on its financial resources.

\section{Introduction}

According to a report by the European Commission (2009) there is no doubt that the global financial crisis initially began in and affected the financial sector of developed economies, specifically in the USA, and then it hurt the real sector of those countries because of unguaranteed loans by the USA financial institution; banks. The impact of the crisis reflected the newly emerging mistrust in the financial system and sector of the US. Looking for urgent solutions was the biggest objective of ex-president George W. Bush and it was one of the biggest challenges that have faced the current president Barak Obama. In the same context, the side effects of this disease spread worldwide and affected the countries mainly whose economies were linked with the USA. Strikingly, this crisis, despite its challenges, has had some positive effects on some of the economies of the world. One of these was Jordan, a country that was moderately affected by the crisis at the beginning, but few months later, its impact was clearly seen in Jordan.

This paper discusses the impact of financial crisis on Jordan in two periods; the first period extended from the autumn of 2008 to December 2008, and the second period which started from December 2008 till the end of 2011. Before that, the paper reviews some previous literature.

\section{Literature review}

In order to have a clear picture of the impacts of the global financial crisis on Jordan, this paper reviews some of the related studies in other countries.

Hussien (2009) studied the impacts of financial crisis on Egypt economy.He pointed out that the stock prices dropped down sharply because of the extensive selling by the foreign investors which affected the local investors. Furthermore, Orozco and Lesaca (2009) reported that some Arabic stock markets have been affected by the crisis such as Saudi Arabia, Kuwait, Doha and Abu Dabi by 50\%. While some other Arabic stock markets were relatively unaffected such as Morocco, Lebanon and Jordan.

Unisif (2009) reported that countries such as Lebanon, Egypt, Jordan, the Occupied Palestinian Territories (OPT), Yemen, Syria, Morocco, and Tunisia are generally highly exposed to western European markets, in terms of both remittances and exports. Therefore, the economic slowdown and rising unemployment in Europe and Gulf Council Countries have had a significant impact in those mentioned countries. In the case of Lebanon, Egypt, Jordan, OPT, Yemen and Syria, almost $50 \%$ to $60 \%$ of the remittances come from the gulf countries, whereas almost $80 \%$ of the remittances in Morocco and Tunisia come from the European countries (Orozco \& Lesaca, 2009). Remittances are considered as vital revenues for those countries because they represent higher percentage in their GDP (Orozco \& Lesaca, 2009).

Apart from Mediterranean countries, Khoon \& Muh-Hui (2010) studied the effects of the crisis in Malaysia and they reported that, the global financial crisis has affected Malaysia in many aspects such as funds flowing, exports and exchange rate. On the other hand, the crisis has had negligible effects in banking sector and unemployment rate. According to that study, the flowing funds into Malaysia dropped sharply from -RM37 billion in 2007 to -RM118.5 billion in 2008. As well as the foreign direct investment declined $17 \%$ in 2008 compared to 2007. This decline in the outflow depress the price of the Malaysian currency, the ringgit lost $6 \%$ of its value against the US dollar. The financial crisis affected the Malaysian export growth; it caused a decline in exports especially manufactured exports. The total exports and the manufactured exports dropped $28 \%$ and $20 \%$ respectively. The Malaysian banking sector was negligible affected by the crisis because of its limited exposure to the US subprime loan products. The banking sector in Malaysia showed a declining trend in overall applications for both business and household sectors. In regard to the unemployment rate in Malaysia, the study reported that the unemployment rate in Malaysia was stable during the crisis and it is a relatively low compared to other countries (Khoon \& Muh-Hui, 2010). 
Adamu (2009) examined the influence of the global financial crisis on Nigerian economy, he found that the financial crisis has caused a substantial fall in the prices of goods and services, decline in export, shrink in the portfolio and foreign direct investment inflows, fall in equity market and a decline in remittances. On a similar study conducted on the U.S economy, (Campello, Graham and Harvey 2009) studied the real effects of financial constraints. They found that the inability to borrow externally causes many firms to bypass attractive investment opportunities with $86 \%$ of constrained U.S. Chief Financial Officers saying their investment in attractive projects was restricted during the credit crisis of 2008. Again Hurd and Rohwedder (2009) studied the effects of the financial crisis and great recession on American households, they found that the financial crisis has dampen the economy of the U.S, thereby causing a widespread between November 2008 and April 2010, approximately 39\% of households had either been unemployed, had negative equity in their house or had been in arrears in their house payments.

This paper discusses the impact of financial crisis on Jordan in two periods; the first period extended from the autumn of 2008 to December 2008, and the second period started from December 2008 till the end of 2011.

\subsection{The First Period}

A year before the financial crisis, Jordan's economy enjoyed good microeconomic performance because of strong trade links that the country had established with the region and other countries around the world, (IMF, $2009 \mathrm{~b}$ ). It is admitted that the crisis had its own sequences on all aspects of the economy, but the effects varied according to the direct relation of the crisis with each sector.

It is natural that when the global financial crisis had broken out in the US, it left local and international impacts. Locally, it initially started to affect the banking sector, and then it affected other sectors such as the real sector. Internationally, it left impact on countries allover the world; especially these had open economic relationships with the USA. Such countries were more affected than others. This means that the countries that had less limits to the international financial market were moderately affected by the crisis. Noticeably, the main reason of the crisis was unguaranteed loans.

In terms of Jordan, the crisis, at the beginning, did not affect the economy, especially the banking sector, because Jordan's financial sector was relatively isolated from the international crisis based on its limited exposure to the international financial market. This protection of Jordan's financial sector helped the country to protect its other sectors.

At the first stage of the crisis, the Jordanian economic ministry reported that they expect positive effects of global financial crisis on Jordan's economy, such as reduction of inflation rates and continuing the growth by at least $5 \%$ in 2009.Mainly, such expectation was established on the bases of the oil price decline, (Al- Jazeera, 2008).

In addition, it was expected by the government that the crisis would affect the economic recession which would, as a result, affect the exports accordingly. Admittedly, Jordan depends highly on grants from donors, but nowadays the donating countries have been affected by the depression, which means that the country will be under the direct influence of the depression growth in the affected countries. In other words, these countries are expected to either stop or reduce their grants to Jordan, (Al-Jazeera, 2008).

However, the Central Bank of Jordan (CBJ) and the banking sector were aware of the emerging danger. So, in order to protect the banking sector, the $\mathrm{CBJ}$ imposed a strict loan classification and provided guidelines for the sector, which reduced banks unnecessary exposure, although, it set interest rate at $10.5 \%$ for housing loans.As a result, the CBJ limited the range of growth while it ensured long-term stability, (European economy, 2009).

The good reaction against the financial crisis in the banking sector in Jordan helped the country to control the crisis internally; they could keep everything under control in this sensitive sector.

The crisis started to affect the country, oil prices gradually went up, the US dollar value declined sharply, remittances from overseas Jordanians declined and foreign grants went down drastically. It was intuitive that Jordan could not overcome these serious challenges. Generally, that drove the country to be affected by the crisis, even though this influence started late in Jordan. The key point is that the crisis had bleak impacts on the country. The impacts of that financial crisis will be discussed in the next part.

\subsection{Second Period}

As all the world is in the midst of the financial crisis which threatens a global economic recession, Jordan, as all parts of the global, has been affected profoundly by the global crisis; all the sectors in Jordan (except the banking sector), have been affected by the crisis. 
In regards to the banking sector, the government could control and protect it successfully because it has the ability to do so, and because the banking sector in Jordan has limited exposure to the global financial market. Therefore, this study tries to highlight the main impacts of the global financial crisis on remittances, inflation rates, exports and imports, exchange rates, consumer behavior, banking sector, tourism sector.

\subsubsection{The Impact of Financial Crisis on Remittances}

As a result of the lack of job opportunities in Jordan, high unemploymentrate, and seeking for better life, the brain drain has been a very common phenomenon. Those working overseas are characterized as very skilled, educated, and professional employees and labors, where they are badly needed in the Gulf region for work mainly in architecture and construction sectors (Abdo \& Ayman, 2010). Consequently, foreign workers in Jordan are known for being unskilled and unprofessional.

Remittances are the most important and tangible benefits of labor migration. Moreover, there are very important source of foreign currency that used by the countries to balance the current accounts (Abdo \& Ayman, 2010). Besides, remittances play an important factor that supports consumer expenditures; on the other hand, they effectively help in reducing poverty.

In many countries, remittances contribute to a high level of GDP. Likewise, remittances in Jordan play a significant contribution in GDP; it forms almost 20\% of GDP (European Commission, 2010). In addition, remittances are important contributor to the country's macroeconomic performance.

Due to the global financial crisis, the remittances declined from 20\% of GDP in 2005 to 14\% of GDP in 2009; it decreased 6\% during the last quarter of 2008 (European Commission, 2009). This reduction of remittances would influence the government and individuals in the same time. It may increase the unemployment rate, particularly among young workers; furthermore, it may increase the poverty rate due to the reduction of a vital source of revenues for households. As a result of the global crisis, the number of Jordanians working in the Gulf region has been declining. That caused another challenge to the government, and caused a huge stress on the laid employees and on their families, because their families rely on them highly and, undoubtedly as mentioned earlier, they have a great contribution to Jordan's economy.

Moreover, the year 2010 displayed a rise of workers' remittances in Jordan; CBJ reported that the remittances increased 2 percent in 2010 compared to its level in 2009; this growth in remittances could help the Jordanian government to overcome the recent economic difficulties. For instance, it will increase the cash inflow of foreign currencies.

The following table shows the Jordanian workers' remittances within the period 2005 to 2010.

Table 1. Jordanian workers' remittances within the period 2005 to 2010

\begin{tabular}{cc}
\hline Year & Workers' remittances (Net) (Million JD) \\
\hline 2005 & 1326.400 \\
2006 & 1531.600 \\
2007 & 1822.900 \\
2008 & 1946.700 \\
2009 & 1899.600 \\
2010 & 1937.500 \\
\hline
\end{tabular}

Source: http://statisticaldb.cbj.gov.jo/index?action=level4

In short, the impact of global financial crisis is like a chain, countries and individuals has been affected, that no one can be excluded, but the impacts can be different from country to country based on its contribution to the global economy and based on its openness to the global economy. In regard to the impacts of global financial crisis on remittances in Jordan, it is noticeable that the impacts were not significant in the early period but after all the region became affected, Jordan was not an exceptional case because the crisis started to affect Gulf countries, where the majority of Jordanians working work, as a result, the number of Jordanian workers decreased because some of them have been laid off. Accordingly, the remittances have declined, to the point that they have seriously affected Jordan's GDP and individuals. 


\subsubsection{The Impact of Financial Crisis on Inflation Rate}

Inflation rates tripled in Jordan (European Commission 2009, and CBJ) because of the rising of fuel and commodity prices. In addition, the fixed currency exchange rate and the abolishing energy subsidies contributed highly to accelerating the inflation rate, which reached to approximately $14 \%$ in the end of 2008 (EU, 2009 and CBJ).

On the other hand, introducing a link between past inflation and public wages could increase the inflexibility of the budget in the future. Moreover, Jordan managed to reduce public debt at a time when the economy was stronger, via a USD 2.1 billion buyback of Paris Club obligations. As a result, public debt fell to $62 \%$ of GDP by the end of 2008 compared to $73 \%$ at the end of 2007 (European Economy, 2009).

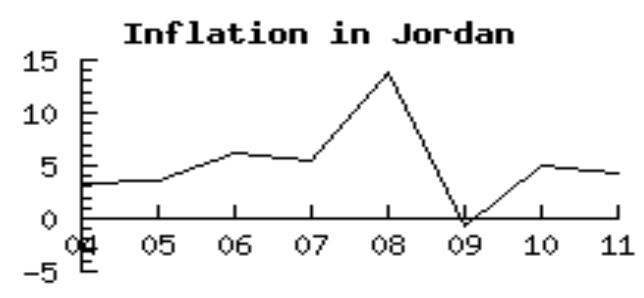

Figure 1. The fluctuation of inflation rate in Jordan

Source: CBJ (http://www.cbj.gov.jo/)

Figure 1 shows the fluctuation of inflation rate in Jordan, it shows obviously how the inflation rate rose up in 2008 to reach 14 percent then dropped to less than zero percent in 2009 , and then started to increase again to reach the normal level in 2011.

\subsubsection{The Impact of Financial Crisis on Exports and Imports}

Jordan is poor-sources country, it is import-oriented, and it is oil-importer country. Noticeably, the price of oil rose up in 2008, which meant that the Jordanian demand became significantly costly. The price rose up to more than $\$ 130$ per barrel in comparison with only $\$ 23$ in 2003. A report by European Economy in June 2009 shows how much Jordan is sensitive to the oil price movement and how it is dependent on a narrow number of trade partners.

On the other hand, Jordan exports chemicals, phosphate and potash, the price of those exports decline significantly, that has negative impacts on the current account deficit, which increased to $24 \%$ of GDP in 2008, additionally, it is expected that falling commodity prices will help the current accounts deficit to narrow to $16 \%$ in 2009 (European Economy, 2009).

$\mathrm{CBJ}$ reported that there is a decline in potash and phosphate export. It can be seen from the date on CBJ that the potash export declined $43 \%$ in 2009 in compare to 2008 and it grew in 2010 by $42 \%$, so the effect was in the year of the crisis only. In regards to phosphate, it declined in 2009 by 17 percent then increased by 21 percent in 2010. The following table shows the quantity of potash and phosphate exported during the period 2005 to 2010 .

Table 2. Jordan's exports of potash and phosphate

\begin{tabular}{ccc}
\hline year & Potash (1000 ton) & Phosphate (1000 ton) \\
\hline 2005 & 1829.000 & 6374.700 \\
2006 & 1728.000 & 5870.800 \\
2007 & 1794.400 & 5541.400 \\
$\underline{2008}$ & 2004.600 & 6265.600 \\
$\underline{2009}$ & 1122.700 & 5152.900 \\
2010 & 1933.500 & 6528.800
\end{tabular}

Source: CBJ (http://statisticaldb.cbj.gov.jo/index?action=level4) 


\subsubsection{The Impacts of Financial Crisis on the Exchange Rates}

Due to pegging Jordanian dinar to the US dollar, the Jordanian monetary policy was enabled to make necessary adjustment to restructure the high cost of oil and some commodity prices, this slow response to the crisis exacerbated the influences of the crisis. The currency exchange rate is fixed in Jordan ( $\$ 1$ is .71 JD), the impacts of this fixed-exchange rate could be in two ways; first: to accelerate the inflation (EU, 2009) and second to have the fuel and commodity by higher price due to the weaknesses of US dollar globally.

Furthermore, the increasing of fuel and foods prices in one hand and the depreciation of US dollar on the other hand have affected the Jordanian exports and have negatively affected Jordan's current account.Whereas pegging the Jordanian dinar with the US dollar leads to maintain monetary confidence while helping to protect the competitiveness of Jordanian exports to the US (European Economy, 2009).

\subsubsection{The Impact of Global Financial Crisis on Consumer Behavior in Jordan}

After the financial crisis has affected the world economy, it became feasible that it has influenced every single in the world. The financial crisis has affected the individuals directly; they feel that their lifestyle has been affected, and they feel that they have to re-evaluate their spending and consumption.As a result, the consumers became more quality aware and savvier shoppers, but remain careful spenders.

In Jordan, due to the decline of remittances, the increase of prices, and the abolishing energy subsidies by the government and the weakness of the dollar, to which the dinar is pegged, Jordanians have been affected significantly by the crisis. A study in Jordan done by Abu Aliqah and Al-rfou (2010) to investigate the impacts of the global financial crisis on consumer behavior in Jordan. They found that $58 \%$ of the respondents were aware of the global financial crisis and its effects on the consumer behavior, $62 \%$ of the respondents reported that the global financial crisis has affected the consumption, about 58\% reported the global financial crisis is causing inflation in Jordan, and almost $67 \%$ of the respondents reported that the global financial crisis has an effect on the Jordanian economy.

Based on the mentioned study (Aliqah \& Al-rfou 2010), they found that $63 \%$ of the respondents reported that they turned to reasonably priced substitute goods, and $61 \%$ of them are buying essential goods instead of buying luxury goods. Moreover, $57 \%$ of the respondents reported that they are buying small quantities of goods, and lastly, the authors found that $71 \%$ of the respondents disagree to shift from the consumption to saving.

In fact, it can be assumed that the remittances are helping Jordanian families to have a good lifestyle, because it is noticeable that Jordanian labors are trying to get an abroad job in order to have better life quality for them and for their families as well.

Due to the decline in the remittances, the Jordanian's purchasing power has been declined too, and which made it worse that the increasing in the prices of essential goods on one hand and the abolishing energy subsidies by the government on the other hand.

\subsubsection{The Impact of Financial Crisis on Banking Sector}

Banking sector is a vital sector in Jordan. Currently, there are 23 banks operating in Jordan: 13 banks of them are local commercial banks, 2 are Islamic banks, and 8 are foreign banks. The latest entrants are National Bank of Kuwait (NBK), BLOM Bank, and Banque Audi. Additionally, the Central Bank of Jordan (CBJ) will license a bank if it offers good potential for developing the banking system in Jordan. However, the CBJ Governor sees little need for new banks at this point in time.

Interestingly, there is an increase in the foreign ownership in banking sector in Jordan; it has increased significantly in 2007, up to $50 \%$ as in the end of June (NBK, December 2008). This increase indicates more confidence in the soundness of the banking sector and its position.

Whereas the banking sector in Jordan is considered sound and well supervised, the Jordanian's government has enhanced the confidence in banks recently by moving to fully guarantee bank deposits during the global financial crisis until the end of 2009. Banking sector in Jordan has not been seriously affected by the global economic crisis due to its limited exposure to international property and equity markets (European Commission, 2010). The limited exposure with global financial markets has bulwarked it from the direct impact of the global financial crisis. As mentioned earlier in this paper, the government of Jordan has guaranteed all bank deposits until the end of December 2009, which leaded to reassure the investors in this sector. In order to deal with the impacts of the crisis in Jordan, the CBJ cut interest rates three times up to April 2009 bringing the benchmark rate to $5.25 \%$ (the lowest since August 2005). At the same time, the CBJ reduced banks' reserve requirements to $7 \%$ (compared with 10\% in October 2008) in order to boost liquidity (European Commission, 2010). 
In short, the financial sector in Jordan has not been affected by the global financial crisis, because of the limitation of its exposure to the international financial market, and because of the policies taken by the government of Jordan and the Central Bank of Jordan (CBJ).

\subsubsection{The Impact of the Global Financial Crisis on Tourism Sector}

Tourism is one of the fastest growing sectors in Jordan; the government of Jordan gives more attention to the tourism sector due to its contribution in developing the economic. Tourism sector plays an important role in the kingdom such as; providing foreign exchange reserves, providing job opportunities, mitigating the pressure on the payment balance, and declining the deficit budget. Recently, two huge projects valued at $\$ 1.8$ billion were approved; whereby Gulf investors would develop tourism infrastructure in the city of Aqaba, primarily through the construction of a number of hotels and apartments. With the inclusion of Petra as one of the new Seven Wonders of the World, Jordan can expect to see greater numbers of tourists over the coming years (NBK, November 2008).

In recent years, Jordan's economic policy has embodied a more long-term view. Tourism sector has been included by the national agenda in its strategic objectives. Noticeably, tourism sector in Jordan finances large trade deficit.Real GDP growth averaged approximately $5.5 \%$ led by the growth in finance and tourism sectors. Tourism inflows increased substantially by 6\%, contributing to $8 \%$ of GDP (European Economy, 2009). Furthermore, the National Bank of Kuwait (NBK), which is a foreign bank in Jordan, reported that receipts from tourism increased considerably, benefiting from the regional abundance of liquidity. Furthermore, the tourism sector has seen a significant amount of foreign investment toward the development of infrastructure, the hotel industry, and the exploitation of Dead Sea minerals for medical purposes (NBK, November 2008).

Similarly, in order to facilitate the investment in tourism sector, the banks in Jordan have facilitated the credits to the industrial and tourism, hotels and restaurants sectors by supporting of the government, which can be seen in the considerable growth in the credits to this sector in 2007 (NBK, November 2008).

Tourism has also been a beneficiary. Unfortunately, the global scene does not bode well for continued growth in this area, (NBK, November 2008). The crisis reduce the tourism revenues in the first half of the year 2009, and this reduction has put the country in a difficult finance and social position, due to the significant increasing in the unemployment levels, particularly among youth and reduction an important financial source of revenues for households.

The tourism sector is also suffering from anapparent dependence of foreign arrivals. Looking at the early figures for the beginning of 2009, hotels have already started to experience the downturn with lower occupancies than last year. Also, the significant amount of supply coming up in the next two years could create additional worries for the hotel industry.

Yet, Jordan's government has taken steps to protect the tourism sector from the impact of the financial crisis by providing sale tax cuts for hotels (from $14 \%$ to $8 \%$ ), to encourage the tourists to visit Jordan (Rosenberg and Choufany, 2009). Those steps led to a real rise in the number of tourists visiting Jordan. The central bank of Jordan (CBJ)' report (2010) shows that the revenue of tourism sector increased gradually and it seemed that the crisis did not affect the sector. The decline of the tourists' number in the beginning of 2009 could be because the tourism season was not started, then after the government's steps, the number increased significantly by 14 percent in compare to 2008 as it is seen in the table 3 .

Table 3. The impact of global financial crisis on the tourism, hotels and restaurant in Jordan

\begin{tabular}{cc}
\hline Year & Tourism, Hotels and Restaurants (million JD) \\
\hline 2005 & 181.200 \\
2006 & 195.100 \\
2007 & 255.800 \\
2008 & 366.600 \\
2009 & 427.900 \\
2010 & 457.300 \\
\hline
\end{tabular}

Source: CBJ (http://statisticaldb.cbj.gov.jo/index?action=level4) 


\section{Conclusion}

The impact of the global slowdown in Jordan can be visible as being driven mainly by the country's high dependence on food and fuel imports, which make it highly vulnerable to fluctuations in food and oil prices (unisif, November 2009). Similarly, whether this crisis has affected Jordanian abroad workers or it has reduced the number of tourists, or decreased the foreign grants.

The banking sector in Jordan was relatively isolated from the impact of the crisis, due to its limitation to the global market and due to the restructure taken by the government and the CBJ.

It can be noticed that the effect of the crisis is like a cycle that will affect everyone, based on the study about the consumer behavior in Jordan after the crisis, it can be concluded that the crisis influenced the consumers in Jordan; the main reasons of this affect are summarized as following:

a) The reduction of remittances has affected Jordanians' purchasing power.

b) The crisis has led to increase the oil and commodity prices which led as a result to decrease the purchasing power too.

c) The increase in the unemployment rate led to increase poverty rates.

Finally, countries should learn good lessons from this crisis in order to be able to protect themselves in the future. Furthermore, they should continue the reform programs to attract the foreign investors.

The year 2009 shows that the country overcame of the crisis impacts and the economy is covered well by some governmental policies.

\section{References}

Abdo, S. D., \& Ayman, D. (2010). The effect of the global financial crisis on migrant workers among MENA countries. International Conference on Economic Modeling.

Abu Aliqah, K. H., \& Al-rfou, A. (2010). The impact of global financial crisis on consumer behavior in Jordan. European Journal of Social Sciences, 12(4), 618-623.

Adamu, A. (2009). The effects of global financial crisis on Nigerian economy. Social science research network. Retrieved from http://ssrn.com/abstract $=1397232$

Campello, M., Graham, J., \& Harvey, R. C. (2009). The real effects of financial constraints: Evidence from a financial crisis. Retrieved from http://www.nber.org/paper/w15552

Central Bank of Jordan. (2012). Retrieved from http://www.cbj.gov.jo/

European Economy. (2009). The Impact of the Global Crisis on Neighbouring Countries of the EUCountries of the EU, Occasional Papers 48, Directorate-General for Economic and Financial Affairs. Retrieved from http://ec.europa.eu/economy_finance/publications

Economic and Social Commission for Western Asia (Escwa). (2009). The impacts of the financial crisis on Escwamember countries: Challenges and opportunities. Retrieved from http://www.un.org/regionalcommissions/crisis/escwacri3.pdf

European Commission. (2010). Implementation of the European neighborhood policy in 2009 country report: Jordan. Commission Staff Working Document. Retrieved from http://ec.europa.eu/world/enp/pdf/progress2010/sec10_525_en.pdf

European Commission. (2011). Implementation of the European neighborhood policy in 2010 country report: Jordan. Commission Staff Working Document. Retrieved from http://mpra.ub.uni-muenchen.de/12604/

Hurd, D. M., \& Rohwedd, S. (2009). Effects of the financial crisis and great recession on American households. Retrieved from http://www.nber.org/paper/w16407

Hussien, A. (2009). Impact of The global financial crisis on the Egyptian economy. Munich Personal RePEc Archive (MPRA).

Jordan Ahli Bank. (2009). Annual report. Rertrieved from https://www.ahlionline.com.jo/

Jones, N., Harper, C., Pantuliano, S., \& Pavanello, S. (2009). The global economic crisis and impacts on children and caregivers: emerging evidence and possible policy responses in the Middle East and North Africa. Retrieved from http://www.odi.org.uk/resources/details.asp?id=4412\&title=global-financial-crisis-impacts-children-caregiv 
ers

Khoon, S. G., \& Mah-Hui, L. M. (2010). The Impact of the Global Financial Crisis: The Case of Malaysia. Third World Network. Retrieved from www.twnside.org.sg

NBK, Jordan. (2008). Economic \& Financial Review.

Orozco, O., \& Lesaca, J. (2009). Impact of the global economic crisis in Arab countries: A first assessment. Retrieved from http://www.clubmadrid.org/img/secciones/Background_Doc_ArabWorld_Eng.pdf

Rosenberg, P., \& Choufany.H. (2009). Jordan A Vital Tourism Sector, HVS. Global Hospitality Services.

Unicef. (2009). Impact of the economic crisis and food and fuel price volatility on children and women in the MENA region. ODI Working Papers 310. Retrieved from http://www.odi.org.uk/resources/details.asp?id=4422\&title=economic-crisis-food-prices-fuel-children-wom en-mena 